\title{
Yabancılaşma ve İbn Haldun'un İlgili Tespitleri Üzerine Karşılaştırmalı Bir Bakış
}

\section{A Comparative View on Alienation and Ibn Khaldun's Related Detections}

\author{
Mustafa ÖZDEMiR \\ Dr. Öğr. Üyesi, Karamanoğlu Mehmetbey Üniversitesi İlami Illimler Fakültesi, \\ Din Bilimleri Anabilim Dalı \\ Asst. Prof., Karamanoğlu Mehmetbey University, Faculty of Islamic Sciences, \\ Department of Religious Studies \\ Karaman, Turkey \\ mustafaozdemir@kmu.edu.tr \\ orcid.org/0000-0001-8402-1877
}

\section{Makale Bilgisi / Article Information}

Makale Türü / Article Types

Geliş Tarihi / Received

Kabul Tarihi / Accepted

Yayın Tarihi / Published

Yayın Sezonu / Pub Date Season : Aralık / December
Cilt / Volume: 8 - Sayı / Issue: 2. Sayfa / Pages: 539-558

Atıf / Cite as

Özdemir, Mustafa. "Yabancılaşma ve İbn Haldun'un İlgili Tespitleri Üzerine Karşılaştırmalı Bir Bakış". Bülent Ecevit Üniversitesi Ilahiyat Fakültesi Dergisi 8/2 (2021), 539-558.

Doi: 10.33460/beuifd.997535

Intihal / Plagiarism

Bu makale, en az iki hakem tarafından incelendi ve intihal içermediği teyit edildi.

This article has been reviewed by at least two referees and scanned via a plagiarism software.

Yayın Hakkı / Copyright ${ }^{\circ}$

CC BY-NC-ND 4.0 | Zonguldak Bülent Ecevit Üniversitesi, Illahiyat Fakültesi tarafından yayınlanmıştır. Telif ve yayın hakları, Creative Commons Atıf-Gayri Ticari-Türetilemez 4.0 lisansının hüküm ve koşullarına tabidir.

CC BY-NC-ND 4.0 | Published by Zonguldak Bulent Ecevit University. Copyrights are subjected to the terms and conditions of a Creative Commons Attribution-NonCommercial-No Derivatives License 4.0.

Öz: "Yabancılaşma" kavramı, gündeme geldiği her dönemde birçok farklı düşünür ve bilim insanının dikkatini çekmiştir. Kavram, tarihi süreç içinde başta felsefi açıdan olmak üzere sosyolojik, dinî, iktisadi vb. birçok farklı açılardan ele alınmıştır. İbn Haldun asabiyetin kaybedilme süreçleriyle ilgili olarak yabancılaşma kavramını andıran görüşlerinde ahlaki bir bozulma ve fitrattan uzaklaşmadan bahseder. Makalenin amacı, ibn Haldun'un "bedevî toplumdan hadarî topluma geçiş" sürecinde ele aldığı hususiyetlerin, yabancılaşma kavramı ile ilişkisini ortaya koymaya çalışmaktır. ibn Haldun'un yabancılaşma başlığı altında ele alınacak olan tespit ve değerlendirmeleri, hangi disiplinin yabancılaşmayla ilgili yorum ve tespitlerine daha yakın durmakta ya da farklılaşmaktadır? Bu ve benzeri sorulara da cevap aranacak olan makalede ibn Haldun'a ait bahsedilen bağlamlar ile yabancılaşma eksenli olarak yapılan tartışmalar arasında çeşitli açılardan karşılaştırma ve değerlendirmeler yapıldı. Ibn Haldun'un hadarî umran yapısına dair tespit ettiği ahlaki bozulma/çözülmelerle ilgili değerlendirmeleriyle kendinden önce ve sonra ortaya konan teolojik/felsefi/ahlakî yabancılaşma teorileri arasındaki benzerlik ve farklııklar ortaya konulmaya çalışıldı. Yapılan karşılaştırmalar 
içinde Karl Marx'ın "yabancılaşma" tespitleri üzerinde hususiyetle duruldu. Elde edilen çeşitli karşılaştırma ve değerlendirmeler, "yabancılaşma" kavramının sosyal bilimler alanında sahip olduğu güncel ve yaygın kullanım potansiyelini göstermesi açısından da ayrı bir önem arz etmektedir.

Anahtar Kelimeler: Din Sosyolojisi, Yabancılaşma, Ibn Haldun, Fıtrat, Öz, Hadarî Umran, Lüks ve Israf.

Abstract: The concept of "alienation" has attracted the attention of many different thinkers and scientists from the moment it came to the fore. This concept, in the historical process, primarily philosophically, sociological, religious, economic, etc. have been studied from many different angles. Ibn Khaldun talks about moral deterioration and alienation from nature in his views resembling the concept of alienation regarding the loss of asabiyya. The aim of the article is to try to reveal the relationship between the characteristics that Ibn Khaldun (ö. 1406) dealt with in the process of "transition from the Bedouin society to the hadarî society" with the concept of alienation. Ibn Khaldun's determinations and evaluations, which will be discussed under the title of alienation, stand closer to or differ from the interpretations and determinations of which discipline about alienation? In the article, in which answers to these and similar questions will be sought, comparisons and evaluations were made from various aspects between the contexts mentioned by Ibn Khaldun and the discussions on alienation. The similarities and differences between Ibn Khaldun's evaluations of moral deterioration/dissolution regarding the hadari umran structure and the theological/philosophical/moral alienation theories put forward before and after him were tried to be revealed. Among the comparisons made, Karl Marx's "alienation" determinations were particularly emphasized. The various comparisons and evaluations obtained are also important in terms of showing the current and widespread use potential of the concept of "alienation" in the field of social sciences.

Keywords: Sociology of Religion, Alienation, Ibn Khaldun, Nature, Essence, Hadarī Umran, Luxury and Waste.

\section{Giriş}

İnsan ve topluma dair birçok farklı araştırma, yorum ve değerlendirme yapılmaktadır. Her bir düşünür sosyal yapının farklı bir unsuruna dair elde ettiği veriler doğrultusunda insana ve topluma yönelik bir çıkarsama yapmaktadır. İbn Haldun'un Mukaddime'sinde çeşitli başlıklarla konu ettiği asabiyet ve umran ilişkisi bağlamında ele aldığı değişimler, bozulma ve çözülmeler yabancılaşma kavramını yoğunluklu olarak akla getirmektedir. Bu sebeple yabancılaşma kavramı merkezinde yapılmış değerlendirmelerden bazılarının incelenerek İbn Haldun'un tespit edebildiğimiz ilgili görüşleriyle benzerliklerin ve farklılıkların tespiti ve çeşitli karşılaştırmaların yapılması bu araştırmanın konusunu oluşturmaktadır. İbn Haldun (ö. 808/1406) da kendi yaşadığı dönemin sosyal yapısını 
teşkil eden temel unsurlarla ilgili çeşitli gözlem ve değerlendirmelerde bulunmuş müstesna düşünürlerden birisidir. Yaşadığı ve gezileri vasıtasıyla gözlemlediği toplum yapılarını, sahip olduğu tarih birikimiyle mezcederek tekrar eden sabiteler ile değişen hususiyetlerin değişim ve çözülme akslarını ortaya koymuştur. ${ }^{1}$

İbn Haldun'un bedevî ve hadarî umranda yaşanan değişim ve sürekliliğe dair tespit ve betimlemeleri dikkat çekmektedir. Makalenin amacl, İbn Haldun'un Mukaddime adlı eserinde belirttiği farklı umranlara ait ahval ve değişimle ilgili unsurları, yabancılaşma kavramı bağlamında tekrar ele alarak güncel bir karşılaştırmasını yapabilmektir. İbn Haldun'un bahsi geçen betimlemeleri yakın planda ele alındığında, birçok farklı açıdan ele alınan yabancılaşma kavramının sahip olduğu anlam içerikleriyle bir takım benzerliklerinin olduğu görülmektedir. Bu benzerliklerden hareketle hem İbn Haldun'un ilgili görüşlerini derleyerek bir araya getirmek hem de yabancılaşma merkezli olarak yapılan bazı çalışmaların İbn Haldun'un vurguladığı hususlarla ilgili benzer ve farklı yanlarının bir tespitini yapabilmek bu araştırmanın amaçları arasındadır. ${ }^{2}$

Amaçlarına göre sınıflandırıldığında keşfedici araştırma türü içinde sayılabilecek olan makalede, doküman incelemesi, eleştirel söylem analizi ${ }^{3}$ ve literatür taraması gibi nitel araştırma yönteminin çeşitli tekniklerinden ${ }^{4}$ yararlanılmış ve kavramın anlaşılmasına katkı sunacak yeni bir kompozisyon oluşturulmaya çalışılmıştır. Yabancılaşma kavramı, birçok farklı açıdan ele alınan bir genişliğe sahip olduğu için ${ }^{5}$ yapılacak karşılaştırmalar, dinî, felsefi, edebî ve sosyolojik yoğunluğa

1 Süleyman Uludağ, ibn Haldun (Ankara, Türkiye Diyanet Vakfı Yayınları: 1993), 1-31. Ayrıca bkz. Süleyman Uludağ, “ibn Haldun", Türkiye Diyanet Vakfı İslâm Ansiklopedisi (Ankara: TDV Yayınları, 1999), 19/538-543.

2 İbn Haldun'un kullandığı temel kavramları güncel başka kavramlar eşliğinde araştıran benzer başka çalışmalar da yapılmıştır. Ayrıca bkz. Bahram Hasanov, "Ibn Haldun'da Asabiyet Kavramı - Maurıce Halbwachs'ın "Kolektif Hafıza" Kavramı İle Bir Karşılaştırma"; Elektronik Sosyal Bilimler Dergisi, 15/59 (2016); Serkan Polat, Semra Aktaş Polat, "Bedevi Ümrandan Hazeri Ümrana Geçiş: Boş Zaman Kültürüne Bir Bakış”, Kastamonu Üniversitesi Iktisadive İdari Bilimler Fakültesi Dergisi, 12 (2016); Olgun Közleme, “ibn Haldun Düşüncesi'nde Geçim ve Zenginliğin PsikoSosyal Boyutları”, Toplumbilimleri Dergisi, 7/13 (2013), 363-376; Akif Kayapınar, “ibn Haldun’un Asabiyet Kavramı: Siyaset Teorisinde Yeni Bir Açılım", İsâm Araştırmaları Dergisi, 15, (2006), [ibn Haldun Özel Sayısı-I], 83-114. İbn Haldun ile ilgili birçok farklı konu başlıkları için bkz. Mesut Okumuş - Ömer Dinç (ed.), Uluslararası Ibn Haldûn Sempozyumu, (Ankara: Çorum Belediyesi Kültür Yayınları, 2015)

3 "Eleştirel söylem analizi, metinde açıkça belirtilen anlamın içinde gizli olan veya ilk anda ima edilen anlamların ötesindeki anlamların ortaya çıkarılmaya çalışılmasıdır." Geniş Bilgi için bkz. Temmuz Gönç Şavran, "Nicel ve Nitel Araştırmalarda Kullanılan Araştırma Teknikleri", Sosyolojide Araştırma Yöntem ve Teknikleri, ed. Temmuz Gönç Şavran (Eskişehir: Anadolu Üniversitesi, 2012), 96.

4 Zeki Arslantürk, Sosyal Bilimciler İ̧in Araştırma Metod ve Teknikleri (İstanbul: Çamlıca Yayınları, 2008). Ayrıca bkz. Gönç Şavran, "Nicel ve Nitel Araştırmalarda Kullanılan Araştırma Teknikleri", 87.

5 Farklı alanlarda yapılmış ilgili bazı çalışmalar için bkz. Sadık Kılıç, Yabancılaşma-Insana Karşı Toplumsal Süreç (İstanbul: Rahmet Yayıncılık, 1984); Bertell Ollman, Yabancılaşma-Marx'ın Kapitalist Toplumdaki İnsan Anlayışı, çev. Ayşegül Kars (İstanbul: Yordam Kitap, 2012); İsmet Özel, Üç Mesele-Teknik-Medeniyet-Yabancılaşma (İstanbul: Çıdam Yayınları, 1992); İsmet Özel, Üç Zor Mesele- Teknik, Medeniyet-Yabancılaşma (İstanbul: TiYO Yayıncılık, 2016); Doğu Ergil, "Yabancılaşma Kuramına İlk Katkılar", Ankara Üniversitesi SBF Dergisi 33 / 03 (Mart 1978); Mahmut Tezcan, "Gençlik ve Yabancılaşma", Ankara University Journal of Faculty of Educational Sciences (JFES) 18/1 (2019); Haci Ömer Özden, "Bir Ahlâk Problemi Olarak Yabancılaşma ve Yahya Kemal", Illahiyat Akademi 2/3 (2016); Mustafa Tekin, "Mevlâna Celâleddin Rûmi'de Din ve Yabancılaşma", Inönü Üniversitesi Illahiyat Fakültesi Dergisi 1/1 (2010); Bilal Sambur, "Din, Ülfet ve Yabancılaşma”, Ilahiyat Akademi 3 (2016); Ferhat Uzunkaya, 1980 Sonrası Türk Romanında Yabancılaşma (Ardahan: Ardahan Üniversitesi, Sosyal Bilimler Enstitüsü, Doktora Tezi, 2020) 
sahip açıların her birini temsil eden bir ya da birkaç şahısla sınırlandırılmıştır. Gerekli görülen ilgili literatür ve kaynaklar taranarak olabildiğince dipnotlarda verilmeye çalışılmıştır. Makalede yapılmak istenen, İbn Haldun'un görüşlerini, kendisinden çok sonra yaşamış olan başta Karl Marx ve diğer düşünürler tarafından ele alınan yabancılaşma kavramı şablonuna oturtmak ya da kavramın yoğunluklu olarak kullanıldığı Marksist düzleme indirgemek değil; bilakis sürekli olarak gündeme gelmiş bir kavram üzerinden felsefî ve sosyolojik gelenekte zaten var olan tartışma ve yaklaşımları, başka açılardan da ele alarak güncel karşıııkları üzerinde yeniden düşünebilmenin imkân ve şartlarını zorlamaktır. Özellikle yabancılaşma kavramını, Karl Marx temelli olarak ele alan bazı çalışmalarda yapılan vurguların, kavramın sahip olduğu ontolojik ve sosyolojik kuşatıcılığı-Marx'ın ele aldığı bağlamdan da kaynaklı olarak- tahsis ettikleri, daralttıkları görülmektedir. Bu bağlamda İbn Haldun'un "fıtrattan uzaklaşma ve ahlaki çözülme" şeklinde ele aldığı yabancılaşma eksenli düşüncelerinin, daha kuşatıcı ve geniş açılardan konuyu ele alan yabancılaşma tanım ve tahlillerine daha yakın oldukları söylenebilir. Bu durumu ortaya çıkarmak üzere makalede cevabı aranan sorular şu şekilde oluşturulmuştur: Yabancılaşma kavramını merkeze alan çalışmalarla İbn Haldun'un Yabancılaşma kavramını andıran çözümlemeleri arasında bir benzerlik ya da farklııı var mıdır? Varsa bu benzerlik ve farklılıklar nelerdir? Karl Marx'ın insanın özüne yabancılaşması şeklindeki tanımı ile İbn Haldun'un fıtrattan uzaklaşma şeklindeki betimlemesi arasında bir benzerlik var mıdır? Bu sorular doğrultusunda makaleye yabancılaşma kavramı üzerine yapılmış açıklama ve tartışmalara kısaca değinilerek devam edilecektir. ${ }^{6}$

\section{Yabancılaşma Kavramı Üzerine Yapılan Tartışmalara Genel Bir Bakış}

Yabancılaşma kavramının kökeni üzerine yapılan bir çalışmada, Almancada 'Entfremdung' ifadesiyle karşılanan kavramın, Fransızcada ve İngilizcede 'alienation' olarak geçtiği; 'alienation' kavramının ise "bir topluluk veya gruba ait olmama duygusu, aidiyet hissetmeme" anlamında olduğu belirtilmiştir.7 Yabancılaşma kavramının Türkçe sözlüklerdeki karşılıklarına bakıldığında ise, "belli tarihsel şartlarda insan ve toplum etkinlikleri ürünlerinin, bu etkinliklerden bağımsız ve bunlara egemen olan ögelerin değişik biçimde kavranması"8 şeklindeki açıklamaların yanı sıra "insanın sosyal hayat karşısında duyduğu huzursuzlukla karışık ruh hali, insanın kendi beninden uzaklaşması, kendine yabancı olma hali, kendi milletinden kültüründen uzaklaşıp başka toplulukların kültürünü, değerlerini benimseme hali"9 gibi açıklamaların yapıldığı da görülmektedir. Bu farklılık yabancılaşma kavramının kullanıldığı bağlamlardan (kontekst) kaynak-

\footnotetext{
6 İbn Haldun'un görüşleri için Süleyman Uludağ'ın hazırladığı Mukaddime baskısı temel alınarak değerlendirmeler yapılmıştır.

7 Sibel Kiraz, “Yabancılaşmanın Kökeni Üstüne”, FLSF (Felsefe ve Sosyal Bilimler Dergisi), 12 (2011), 150-152.

8 Türk Dil Kurumu, Türkçe Sözlük (Ankara, Türk Dil Kurumu Yayınları: 2005), 2102.

9 D. Mehmet Doğan, Büyük Türkçe Sözlük (İstanbul, İz Yayıncılık: 1996), 1123.
} 
lanmaktadır. Bütün bağlamlarda, var olan, devamlılığı bulunan ve korunması gereken bir asıl ve bu asıldan farklılaşmış/uzaklaşmış/manipüle edilmiş/çarpıtılmış yapı ve durumlardan bahsedilebilir. Mevlana'nın Ney'in Feryadı́nda "aslından uzak düşen kişi, yine vuslat zamanını arar"10 diyerek anlatmaya çalıştığı ney ve kamışlık ilişkisi, bağlamına göre yabancılaşmaya bir örnektir. Bundan başka Franz Kafka'nın böceğe dönüşen Groger Samsa örnekliği üzerinden anlatmaya çalıştığı durum da, Marx'ın da üzerinde durduğu kapitalist üretim sistemi içindeki bireyin yaşamış olduğu manipülatif/çarpıtılmış bir yabancılaşmaya örnek olabilir. ${ }^{11}$ Yabancılaşma kavramının vurgulanan bağlama göre çeşitlenmesine örnek olarak topluma, aileye, kendine, dine, düzene, mekâna, yaşama yabancılaşma, ayrıca kültürel yabancılaşma, bilge yabancılaşması, bürokratik yabancılaşma, ekonomik yabancılaşma, epistemolojik ve enformatik yabancılaşma ${ }^{12}$ gibi örnekler verilebilir. Görüldüğü üzere yabancılaşma kavramı, "olandan kopuş, başka bir alana ait olma, farklı olma, başkalaşma kavramları ile ilişki içerip dışlayıcı bir nitelik taşır."13

Yabancılaşma kavramı ile ilgili farklı bağlam ve içeriklere dair örnekler, makalenin ilerleyen bölümlerinde verilecektir. Bu bağlamlar eşliğinde farklı anlam yelpazesine sahip olan yabancılaşma kavramının, İbn Haldun'un kullandığı bağlamla olan ilişskisi, benzer ve farklı yönleri ortaya konmaya çalışılacaktır. Özellikle Karl Marx'ın vurgusunu yaptığı bağlamla İbn Haldun'un vurgusunu yaptığı bağlamın farklı görüşler ve değerlendirmeler ışığında bir karşılaştırılması yapılacaktır.

\subsection{Bağlamlarına Göre Yabancılaşma Teorileri}

Yabancılaşma (alination) kavramı, her ne kadar Karl Marx'ın ekonomik bağlamda gündeme getirerek tartışmaya açtığı bir kavram olsa da kavramın arka planında felsefeden teolojiye, psikolojiden edebiyata kadar farklı disiplinlerin de içinde olduğu yaklaşım ve değerlendirmelerin olduğu görülmektedir. Farklı bağlamlar eşliğinde yapılmaya çalışılacak olan bu değerlendirmeler, aynı zamanda İbn Haldun'un yabancılaşma kavramı ile ilgili değerlendirmelerinin daha net anlaşılmasını sağlayacak bir düzlem de oluşturacaktır.

Felsefi alanda yabancılaşma kavramını Platon üzerinden açıklamaya çalışan çeşitli tartışma ve değerlendirmeler yapılmaktadır. "Platon'a göre insan varlık âleminden, evrenden koparak hem ideal bilgilerin kendinden hem de ideal varlıklar sebebiyle iyi ve güzel ideasından uzaklaşmış ve yabancılaşmıştır."14 "Yabancı-

10 Mevlana Celaleddin Rumi, Mesnevi, çev. Veled İzbudak (İstanbul: Milli Eğitim Bakanlığı Yayınları, 1990), 1/1.

11 Franz Kafka, Dönüşüm, çev. Nafer Ermiş (Ankara: Imge Kitabevi, 2008).

12 Selma Baş, Türk Hikâyeciliğinde Yabancılaşma (1950-1980), (Van: Yüzüncü Yıl Üniversitesi, Sosyal Bilimler Enstitüsü, Doktora Tezi, 2003).

13 Bayram Dalkılıç - Yakup Akyüz, "Platon'un Felsefesinde Yabancı/laş/tır/ıl/ma Sorununa Giriş Denemesi”, Hikmet Yurdu, 11/21 (2018), 9-27.

14 Dalkılıç-Akyüz, "Yabancı/laş/tır/ıl/ma Sorununa Giriş Denemesi”, 22. 
laşmayı metafizik bir problem olarak ortaya atan Hegel'dir."15 "Hegel felsefesinin temelinde, felsefenin merkezî problemlerinden biri, yabancılaşma ve yabancılaşmayı aşma meselesi yatmaktadır. Hegel, diyalektik idealizmle bu probleme hâkim olmaya çalışmaktadır. Yabancılaşmayı yok etmek için külli vahdete sahip olmak lâzımdır."16 Hegel'in anlayışında "insan zihnî ürünleri kaynağından bağımsızlaşır ve böylece ona yabancılaşır."17 "Hegel'e göre içsel bir eleştiri yoluyla, bir bilgi biçiminin nasıl kırıldığını ve kendinden öteye işaret ettiğini göstermek son derece lüzumludur. Her bir çağda, her birimiz belli noktalarda 'temellerin sarsıldığını' ve olduğumuzu düşündüğümüz şeyle gerçekte ne olduğumuz arasında bilinçlilik düzleminde içsel bir gerginlik yaşadığımız hissedebiliriz."18

Yabancılaşma kavramının son dönem sosyal bilimler disiplini içinde yoğunluklu olarak gündeme gelmesinde ve kavramın daha gerilerdeki düşünsel köklerine yönelik araştırmalar yapılmasına sebep olması açısından Karl Marx'ın yabancılaşma hakkındaki düşüncelerinin biraz daha geniş düzlemde ele alınması, hiç şüphesiz konunun daha iyi anlaşılmasına katkılar sunacaktır. Skirbekk ve Gilje'e göre, Yabancılaşma teorisi, Marx'ın Hegel'in yoğun etkisi altında olduğu ilk eserlerinde ilhamını Ludwig Feuerbach'tan alarak geliştirdiği bir teoridir. Feuerbach, yabancılaşmayı insanın kendi ürettiği süreçler marifetiyle kendilerine ait kimi parçalarına yabancılaşması şekliyle yorumlar. Ona göre insanlar kendi imal ettikleri Tanrı sureti tarafından baskı altına alınmışlardır. ${ }^{19}$ Marx, Hegel'in idealist- metafizik yabancılaşmasına sosyal bir muhteva kazandırmıştır. ${ }^{20}$ "Hegel, süje merkezli düşünceyle yabancılaşma kavramına içsel bir açıklama getirirken; Marx, tam aksine bireyin bilinçsizleşmesine ve kendi benliğinden kopmasına vurgu yapmaktadır."21 Yani kapitalist üretim biçiminin ortaya çıkardığı emek ve çalışma biçimleri insanı birçok şeyden (insani özünden, işinden, emeğinden, ortaya koyduğu ürününden, toplumdan) uzaklaştırarak yabancılaşmasına sebep olmuştur.

Marx'ın diyalektik düşüncesi içinde temellendirmeye çalıştığı yabancılaşma kuramında temel gösteren ekonomidir. Marx'ın yabancılaşma kavramı, tüm dünya tarihini kendisiyle anlatıp değerlendirmeye çalıştığı "çatışma kuramı" içerisindeki temellendirmelerinde kullandığı, özellikle kapitalist ekonomik sistem anlatısında daha da somutlaştırdığı işlevsel bir kavram olmaktadır. ${ }^{22}$ Ona göre insanlık tarihi, ekonomik anlamda üretim araçlarına sahip olanlar ile olmayan-

15 Özel, Üç Zor Mesele, 114.

16 Orhan Münir Çağıl, “Metafizik Zaviyeden Yabancılaşma Problemi ve Hegel'in Panlojist 'İntikal Ve Telif (Terkip)' Felsefesi", İstanbul Üniversitesi Hukuk Fakültesi Mecmuası, XLIV/1-4 (1980), 137-138.

17 Özel, ÜçZor Mesele, 114.

18 Gunnar Skirbekk - Nils Gilje, Antik Yunan'dan Modern Döneme Felsefe Tarihi, çev. Emrah Akbaş-Şule Mutlu (Ankara: Kesit Yayınları, 2011), 395.

19 Skirbekk - Gilje, Felsefe Tarihi, 413.

20 Özel, ÜçZor Mesele, 115.

21 Dalkılıç-Akyüz, "Yabancı/laş/tır/ı/ma Sorununa Giriş Denemesi", 23.

22 Slattery, Sosyolojide Temel Fikirler, 126. 
lar arasında geçen bir sınıf mücadelesinden ibarettir. ${ }^{23}$ "Kapitalist iş ilişkilerinin merkezini oluşturan fabrikalarda kitle üretimi yapılır ve işler bölünebilecek en küçük parçalara ayrılır. Kitle üretiminde işçi tek bir işi tekrar tekrar gerçekleştirir, çalışanın psikolojik/duygusal/ insani boyutu göz ardı edilir. Çalışana makinanın bir uzantısı gibi bakılır. Aylarca aynı işi yapan işçi bir süre sonra yaptığı işe yabancılaşır." ${ }^{24}$ Çünkü mekanik bir robottan farksız, sadece işlerine odaklanan işçiler, yetenek ve kabiliyetlerini yitirmiş bir şekilde iç dünyalarında hapsolmuş varsayılmaktadır. 25 "Marx'a göre, dini yabancılaşmanın ortadan kaldırılması öncelikli olarak ekonomik yabancılaşmanın ortadan kaldırılmasını gerektirir. Dinî yabancılaşma ekonomik yabancılaşmaya dayalı siyasi ve sosyal yabancılaşmadan kaynaklanır. Bu anlamda ekonomik (materyal) etken ruhani etken üzerinde önceliğe sahiptir. Marx insanların dinî anlamda yabancılaştıkları fikrini kabul eder. Ancak böylesi bir yabancılaşma Marx'a göre en önemlisi değildir. Bu dinî yabancılaşma kapitalist toplumdaki genel yabancılaşmanın sadece tek bir yönüdür."26

Raymond Aron, Marx'ın yabancılaşma görüşü ile ilgili olarak daha çok felsefi temelden beslenen ama sosyolojik bir yoğunluğa sahip olduğu tespitlerini yapar. "Kapitalizmin ekonomik gerçekliğinin eleştirisi, Marx'ın düşüncesinde başlangıçta felsefi ve ahlaki bir eleştiriydi; sonradan tamamen sosyolojik ve ekonomik bir incelemeye dönüştü... Onun için kapitalist ekonominin incelenmesi, özerk yasaların egemenliğindeki bir sistemin kendi varlıklarının denetimini yitiren insanların ve toplulukların yabancılaşmasının incelenmesidir."27 Yabancılaşma konulu çalışmalarda kendisine sıkça atıfta bulunulan Bertel Ollman'a göre, kısaca Marx'ın kapitalist toplum yapısındaki insan anlayışı olarak da özetlenebilecek olan "yabancılaşma kuramı, Marx'ın kapitalist üretimin insanoğlunun fiziksel ve akli durumu ile bir parçası olduğu toplumsal süreç üzerindeki yıkıcı etkisini gösterdiği entelektüel yapıdır."28 Ollman'ın vurguladığı hususlara bakıldığında yabancılaşma kavramının muhatabının sadece işçiler ve kapitalist toplum yapısı olduğu gibi bir sınırlandırma/tahsis akıllara gelmektedir.

Yabancılaşma kavramı ile ilgili olarak metafizik/teolojik, ekonomik ve sosyolojik düzlemlerden yapılan açıklamalara, İslam dininin perspektif ve terminolojisinden istifade eden birkaç isim üzerinden de çeşitli örnekler verilerek konuya devam edilecektir. Bu şekilde İslam düşünce geleneğinde çok önemli bir yeri olan İbn Haldun'un, yabancılaşma başlığı altında niçin ele alınmaya çalışıldığı sorusuna da naif bir geçişle cevap aranmaya ve tartışılmaya çalışılacaktır.

23 Slattery, Sosyolojide Temel Fikirler, 105.

24 Memet Zencirkıran, Sosyoloji, (Bursa, Dora Yayıncılık: 2019), $42-43$.

25 Bekir Koç, "Yabancılaşma ve Modern Tüketim Mabetleri Üzerine Bir Çözümleme”, Bingöl Üniversitesi Illahiyat Fakültesi Dergisi 1/2 (Ekim 2016), 207.

26 Skirbekk-Gilje, Felsefe Tarihi, 414.

27 Raymond Aron, Sosyolojik Düşüncenin Evreleri, çev. Korkmaz Alemdar, 8. Baskı (İstanbul: Kırmızı Yayınları, 2010), 131.

28 Ollman, Yabancılaşma, 213. 
Teolojik düzlemde yabancılaşma kavramını insanın yaratılışı bağlamında Tanrısal özden bir kopuş, fıtrattan uzaklaşma gibi bağlamlar içinde ele almaya çalışan yaklaşım ve değerlendirmeler görülmektedir. Türk toplumu özelinde yabancılaşma kavramını sahip olduğu sol içerime sahip yorumlamaların ötesinde İslami bakış açısı ile birlikte açıklamaya çalışan ilk isimlerden biri olarak İsmet Özel gelmektedir. Özel, Üç Mesele ve sonrasında Üç Zor Mesele diyerek ele aldığı yabancılaşma kavramını, var olan durumun bir tespitinden ziyade olması gerekenin tavsifinin doktriner bir tarzla işlendiği bir vurguyu öne çıkarmaktadır. Felsefi ya da teolojik düzlemde insanın yabancılaşması, bir sorunsala işaret ediyorken Özel'de çağın akıl düzenine, iktisadî ve toplumsal işleyişine uzak kalabilmesine imkân tanıması açısından bir farklıı̆ğa kapı da aralamaktadır. ${ }^{29}$ Ona göre "Müslümanın meselesi yabancılaşma kavramının çok ötesinde bir "yabancılaşma" ile açıklanabilecektir. Ancak bazı imkânlara sahip kafalardır ki genelgeçer doğruları aşıp, onlara ve insanın kendini gerçekleştirme vehmine yabancılaşıp Hakikatin yönüne yüzlerini çevirirler." ${ }^{\prime 30}$ Özel, Modern zamanların yabancılaşma anlatısını, kendisine bakarak yabancılaştıklarına karar verecekleri bir temel zemin, öz ya da kültürün olmayışı ya da var olduğunu iddia ettikleri bu özün de müphem, flu ya da tartışmalı olması yüzünden bu iddia ve çözümlerin vehimden öteye geçemediklerini söyleyerek eleştirmektedir. Varoluşsal bakımdan insanın kendisine yabancılaştığını söyledikleri "öz"ün belirleyicisinin, kaynağı kendinden menkul, açıklamaları içinde Allah'a yer vermek istemeyen, mutluluğu kullukta gören kitaplı dinlerin anlayışını da tartışma dışı bırakan hümanizm olduğunu söylemektedir. Ona göre, hümanizm anlatısı çerçevesindeki bir yabancılaşma anlatısının, sorunları tespiti de çözümü de bir kısır döngüyle sonuçlanacaktır. Oysa insan kim olduğuna ancak Allah'ın koyduğu çerçeveden bakarsa sorunlarını ve çözümlerini doğru şekilde tespit edebilir. Bu tespitini konuya girişte kullandığı Asr suresi ve bazı ayet mealleriyle de desteklemektedir. ${ }^{31}$ Son olarak Özel, "yabancılaşma, insanın değerler bakımından yoksullaşması noktasından kalkan bir görüş. İnsanın parçalandığı ve asli değerlerinden birçoğunu kaybettiği, dine bağlı anlayışın da kabulleri arasında" diyerek İslam fıtratına vurgu yapmış ve yabancılaşma kuramcılarının, geçmişte yalnızca bir yabancılaşma süreci görebildiklerini, bu yüzden 'insan yabancılaşmıştır' cümlesinin de anlamdan yoksun kaldığını belirterek konuyu özetlemiştir. ${ }^{32}$

Illahiyat disiplini içerisinde, yabancılaşmanın fıtrat eksenli olarak ele alınmasında ve gündeme getirilmesinde önemli katkıları olan Sadık Kılıç, Yabancılaşma adlı çalışmasında konuyu birçok farklı açıdan ele alır. ${ }^{33}$ Kılıç'a göre Allah'a kulluk

29 Özel, Üç Zor Mesele, 114.

30 Özel, ÜçZor Mesele, 115.

31 Özel, ÜçZor Mesele, 116-131.

32 Özel, ÜçZor Mesele, 129.

33 Jean Paul Sartre, Kierkegaard, Aldous Huxley, Albert Camus, Erick From gibi birçok ismi içine alan geniş bir yelpazede konuyu işlemeye çalışmıştır. 
ruhunu yok etme istikametinde bir ekonomik süreç, teknolojik çılgınlık, sosyal ve ferdi yabancılaşmayı, çürümeyi ve mutsuzluğu beraberinde getirecektir. Yani Kılıç'ın yabancılaşma hakkındaki düşünce ve değerlendirmeleri, Allah'ın koymuş olduğu denge ve ahengin, Allah'ı unutan insan eliyle kendi aleyhine olacak şekilde bozulmasıdır şeklinde özetlenebilir. ${ }^{34}$ Kılıç, "Yabancılaşma karşısında İslam'ın Yaklaşımı" başlığı altında insanın içine düşmüş olduğu asıl yabancılaşmaya ve ondan kurtuluşun yolları üzerine çeşitli değerlendirmelerde bulunur. Ona göre yabancılaşma vakıası baştan sona kadar Kur'an'ın konusunu oluşturur. Kur'an'ı Kerim muhtelif ve zengin sunuşlarıyla, kendi öz benliğine, öz gayesine yabancılaşmamış insanı oluşturmak ister. Bu hususlar ise, Asr suresinde dört şık halinde veciz bir ifadeye kavuşturulmuştur. İlk iki yol (İman ve amel) bireyin kendisini yabancılaşmadan koruması için gerekli ferdi ön-şartlardır. Son iki şık (hakkı ve sabrı tavsiye) ise öncekilerinin devamı olarak başkalarını yabancılaşma sürecine girmekten uzak tutma eylemini gösterir. ${ }^{35}$ Ayrıca Kılıç, konumuzla birebir alakalı olarak İbn Haldun ve yabancılaşma konusunu da ele alan müstakil bir başlık açmıştır. Söz konusu tespitleri İbn Haldun'da yabancılaşma kavramı ele alınırken ayrıca değerlendirilecektir.

Bunlarla birlikte yabancılaşma kavramını ele aldıkları farklı konu başlıkları bağlamında işleyen, kavramla ilgili çeşitli göndermelerde bulunan bazı çalışmalardan da bahsedilebilir. Örneğin Gürses, sufi/mistik bakışla psikolojik bakışı mezceden bir yorumla ele aldığı çalışmasında "İnsan, içine doğduğu dünyanın bilgisini kendisine veren ve dolayısıyla kendisiyle ve evrenle yabancılaşmasını önleyen ilk örneklere, ilk fikirlere (arketip/ayan-ı sabite) sahiptir."36 diyerek yabancılaşmaya bir gönderme yaparken; Erdiç, siyaset-yargı ilişkisi bağlamında Ebu Hanife ile dönemin yöneticilerinin ayrı düşmesini, bir tür siyasal alanın yeni uygulamalarının, mevcut hukuki ve dinî uygulamalar alanından uzaklaşması şeklinde vurgusunu yaptığı bir yabancılaşma olgusundan bahsetmiştir. ${ }^{37}$ Yabancılaşmanın dinle kurulan pozitif ve negatif ilişkinin, din ve yabancılaşma ilişkisini oldukça ilginç kıldığına değinen Tekin'e göre; “Din, kimi zaman yabancılaşmanın sebebi olarak görülürken, kimi zaman da yabancılaşmaya karşıt bir fenomen olarak ortaya çıkmaktadır." ${ }^{\prime 3}$ İnsanın yeryüzündeki varoluş mücadelesinin içinde bulunduğu yabancılaşma ile eşzamanlı süren bir mücadele sonunda anlam kazandığına vurgu yapan Karaca'ya göre bu mücadelede Din/Vahiy insanın yabancılaşmasında ona yol ve yön gösterecek en asli unsurdur. Ama bu asli rehber doğru anlaşılıp yaşanmadığı takdirde başka bir yabancılaşmaya kapı aralamasının söz

34 Kılıç, Yabancılaşma, 44-139.

35 Kılıç, Yabancılaşma, 110-111.

36 İbrahim Gürses, "Jung'cu Arketip Teorisi Bağlamında Tasavvufî Öykülerin Değerlendirilmesi: Sîmurg Örneği” T.C. Uludağ Üniversitesi Illâhiyat Fakültesi Dergisi, 16/1 (2007), 95.

37 Şaban Erdiç, "İslam Düşüncesinde Yargı ve Siyaset İlişkisi: Ebû Hanîfe Üzerine Sosyolojik Bir Değerlendirme", Cumhuriyet ilahiyat Dergisi 25/1 (Haziran 2021), 298-307.

38 Mustafa Tekin, "Mevlâna Celâleddin Rûmi'de Din ve Yabancılaşma” İnönü Üniversitesi Illahiyat Fakültesi Dergisi 1/1 (Haziran 2010), 102. 
konusu olabileceğini belirtirken; dini hayatlarına rehberlik etmeleri için aklını, bilişsel yeteneklerini, başkalarının hizmetine sunan insanlar ile dini yanlış, eksik öğrenen veya yeterince öğrenemeyen, onu hurafelerden ayırt edemeyen dindarların da yabancılaşmaya daha açık pozisyonda olduklarının hatırlatmasını yapar. ${ }^{39}$ Benzer bir şekilde aynı tehlikeye dikkat çeken Tekin ise ilgili başka bir makalesinde "kimi zaman konformizme kayan dini anlayış ve pratikler doğrultusunda Müslümanların dine dair iddialarında bir gerçekleştirim olarak irtifa kaybı yaşandığını ve üretilen yeni dini kültür ve pratiklerin bir yabancılaşmayı beraberinde getirdiğini"40 belirterek var olan bazı dindarlaşma şekil ve pratiklerinin dindarâne yabancılaşmaya sebep olabilme potansiyeline de vurgu yapmaktadır.

\section{2. İbn Haldun'un Yabancılaşmayla İlgili Bazı Tespitleri}

İbn Haldun'un yabancılaşma olarak adlandırılabilecek tespitlerinde "asli halden uzaklaşma" şeklinde vurguların çok olduğu görülmektedir. Onun yabancılaşmayla ilgili düşüncelerinin merkezinde şu tespitleri yer almaktadır:

“iki huydan biri hangi ölçüde daha evvel nefse gelir ve yerleşirse, nefs diğerinden o nispette uzaklaşmış, onu kazanması o derece güçleşmiş olur. İmdi hayır (ve fazilet) sahibi bir kişinin nefsine önce hayırlı ve iyi âdetler yerleşir ve nefsinde hayır işleme melekesi hâsıl olursa, o kişi artık şerden ve kötülükten uzaklaşmış, şerrin yolu onun için zorlaşmış olur. Daha önce nefsine şer ve kötü âdet ve itiyatlar gelip yerleşen şerli ve kötü kişiler için de durum böyledir." ${ }^{\prime 41}$

İbn Haldun, nefsin ilk fıtrat üzere bulunmasının önemine vurgu yapar; bunun için de fitrat hadisinden istifade eder. ${ }^{42}$ Fıtrat onun için, sonrasında insanın toplumsallaşmasını devam ettirdiği ortama göre nefsin yönelimine açık nötr bir kavram gibi durmaktadır. Bu nötr durum, bedevî ve hadarî umranlarda, nefsin hayır ve şerre yönelmesiyle bozulacak, iyi ya da kötü bir şekilde şekillenecektir. Bedevîlerin iktisatlarındaki/geçim yollarındaki değişimin tezahürleri, ihtiyaçların zaruri olanından kemalî (lüks) olanına doğru kaymaya başlaması ile kendini gösterir. Yani bir umranda zaruri olandan daha fazlası için bir yardımlaşma, gıda ve yiyecekleri çoğaltma ve daha geniş evler, şehir ve kasabalar yapmalar görülüyorsa o umran artık yerleşik (hadarî) umranda karar kılmıştır. İbn Haldun, hadarî umranı betimlediği ilgili kısımda daha çok vurgu insanlar için her şeyin daha

39 Faruk Karaca, “Din ve Yabancılaşma: İmkânlar, Fırsatlar ve Tehlikeler". Ilahiyat Akademi, 3 (2016), 49-50.

40 Mustafa Tekin, "'Din'dârâne Yabancılaşma", Illahiyat Akademi, 3 (2016), 56.

41 İbn Haldun, Mukaddime, haz. Süleyman Uludağ (İstanbul: Dergâh Yayınları, 2009), 1/326-327.

42 İbn Haldun'un Mukaddime'de de yer verdiği hadis şu şekilde geçmektedir: "Her çocuk fitrat üzere doğar. Sonra anne babası onu Yahudi veya Hıristiyan veyahut Mecusi yaparlar", Buhari, "Cenaiz", 92. Hadis literatüründe ve sonrasında insanın doğası, kaderi ve eğitimi gibi birçok farklı konuda gündeme gelen bu hadis üzerinden birçok tartışma ve araştırma yapılmıştır. İbn Haldun'un hadisi ele aldığı bağlam ve sonrasındaki değerlendirmelerinin de bireyin toplumsallaşma süreçlerindeki etkenlerle birlikte düşünüldüğünde yerinde ve isabetli olduğu görülmektedir. Çocuk ilk doğduğu andan itibaren başta ailesi olmak üzere birçok toplumsallaşma süreçlerinin (bedevî ve hadarî umran da dâhil) aktif ya da pasif istemli ya da istemsiz uygulayıcısı olarak hayatına devam etmektedir. 
iyisinin gözetildiği bunun için, detay derecesinde konfora ve tüketim nesnelerine yöneldikleri şeklindedir. "Gıdaların terbiye edilmesi, yemek yapılan kapların güzelleşmesi, pişirilen yemeklerin nefaseti, ipek ve atlas gibi kumaşlardan elbise edinilmesi, ev ve konakların yükseltilerek sağlam, süslü ve sanatkârane ve görkemli olmalarına aşırı derecede önem verdiler"43 diyerek hadarî umrana arız olan durumları özetlemeye çalışmıştır. Başka bir karşılaştırmasında ise İbn Haldun, "bedevîler (iktisadî) halleri itibariyle zaruri ihtiyaç maddeleriyle yetinmek zorundadırlar ve ilerisine güç yetiremezler. Hadarîler ise (maişetteki) halleri ve âdetleri itibariyle refah ve lüks nevinden olan ihtiyaç maddelerine itina gösterirler"44 şeklinde tespitler yapmıştır. İbn Haldun bolluk ve refahın, bozulma ve yabancılaşmaya sebep olduğunu sıkça belirtirken, üretim ve tüketimdeki hikmetin gözetilmediği bir toplum örgüsünü itibara almıştır. ${ }^{45}$ Yani İbn Haldun için hadarî umran, içinde barındırdığı her tür potansiyel saikler sebebiyle kişiyi, ilk fıtratı üzere kalmasından uzaklaştırarak yabancılaştırmaktadır. Hadarîlikte insana arız olan bu tür lüks ve israf durumlarını betimleyen daha birçok tespit ve değerlendirme yapmıştır. İbn Haldun'a göre hadarîler, "huzur ve rahatılı döşeğinde sereserpile uzanmış, nimet ve refah denizine dalmış oldukları için mallarını ve canlarını savunma işini kendilerini sevk ve idare eden görevlilere havale etmişlerdir, bu durum da bedevîleri hadarîlerden daha cesur yapmıştır." ${ }^{\text {"6 }}$

Bununla birlikte burada şu hatırlatmayı ve tartışmayı da yapmak gerekli görülmektedir. İbn Haldun, fıtratı ifsat edici potansiyeli üzerinden hadarî umrandaki insanın ahval ve değişimini bedevî umranla karşılaştırırken determinist bir tavra da kaçmamaktadır. Örneğin bedevî umrandaki insanın çeşitli hasletleri öne çıkarılırken bedevî yaşam tarzının getirmiş olduğu yaşam koşullarının sade ve bozulmamışlığının yaşamsal bir döngü ve etkilenimde bulunduğunu anlatmaya çalışır. Bedevî umrandaki insan, zaten hadarî umrandaki ya da şehirdeki insana göre israfa, konfora ya da sapkınlığa düşecek bir sosyo-ekonomik ve demografik etkenden uzaktır. Buna mukabil bedevî ve hadarî umran yapılarını, insanı birden ifsat ya da ihya eden, siyah beyaz şeklinde bir kategorik ayrımdan ziyade, bedâvetten hadarete yaşanan her tür değişim skalasının-mütemadiyen devam ettiği ve dönüştürdüğü bir insan profilinden bahseder. "Göçebelerin zamanla zaruri olanı teminde bir noktaya gelip hâcî olanı düşünmeye başlamaları, çevrelerini yavaş yavaş kontrol altına almaları, o çevrenin sağladığı imkânları kullanmaya başlamaları anlamına gelir ki bu da yerleşik hayata geçmek demektir." ${ }^{\prime 47}$

İbn Haldun'da "asabiyet kavramı" umrandaki bütün değişime yönelik betimlemelerinde kullandığı anahtar bir kavram olarak işlev görmektedir. Cabirî, İbn

\footnotetext{
43 İbn Haldun, Mukaddime, 1/324.

44 İbn Haldun, Mukaddime, 1/325-326.

45 Sadık Kılıç, Yabancılaşma, 42.

46 İbn Haldun, Mukaddime, 1/329-330.

47 Tahsin Görgün, "ỉbn Haldun, Görüşleri”, Türkiye Diyanet Vakfı İlâm Ansiklopedisi (Ankara: TDV Yayınları, 1999), 19/548.
} 
Haldun'un asabiyet kavramını "kendi dönemine kadar gelen İslam tarihi boyunca ortaya atılmış olan bütün problemleri halledebilecek yegâne anahtar olarak kabul ettiğini" belirtir. ${ }^{48}$ Bu bağlamda İbn Haldun için asabiyet kavramı, umranın hal ve gidişatını kendisiyle anlatmaya çalıştığı, bir nevi sosyal bilimler metodoloji içerisindeki "operasyonelleştirilmiş" bir kavrama dönüşmektedir. ${ }^{49}$ İbn Haldun'da iki farklı çözülme durumundan bahsedilebilir. Birincisi hanedanlıkların sahip olduğu asabiyetin, kolektif bilincin, topluluk ve birliktelik hissinin zayıflaması ve kaybolmasıdır ki bu 40'ar yıl üzerinden üç nesil devam edip tamama eren bir süreci içerir. Diğer bir çözülme kişilerin mevcut fitrat potansiyellerinden uzaklaşması anlamında kullandığı çözülmedir. Bu durumla ilgili yaptığı karşılaştırmalarda doğuştan/fıtrattan gelen bazı hasletlere (cömertlik, yiğitlik vb.) bedevi umran düzeyindeki kimselerde daha yoğun ama hadarî umran düzeyindeki kimselerde daha az olduğunu söylüyor. ${ }^{50}$

İbn Haldun'a göre bedevî umran düzeyinde ahlaki çözülme daha az ve yavaş olduğu için insanlar fıtrata daha yakındırlar ve doğuştan getirdikleri fıtrat unsurlarını devam ettirirler. Ama hadarî umranla birlikte gelen bolluk ve israf ahlaki bozulmayı ve fıtrata uzaklaşmayı beraberinde getirir. İbn Haldun'a göre hadarî umranda iş ve meslekler çeşitlenmiş nüfus ise artmıştır. Bu durumda insanın ahlakının bozulmasını hızlandıran bir süreç olarak yansımaktadır. Benzer tespitleri Tekin'in ifadelerinde de görmek mümkün: "şehirlerin nüfusunun artışı, şehirleşme, kültür endüstrisi, popüler kültür, hızlı iletişim insanın ruhunu, kendisine bile yetişmesini zorlaştırırken, şiddetin yaygınlaşması, demoralizasyon, geleneksel ilişki ağlarının çökmesi ve şizofreninin artışı bize adres olarak yabancılaşmayı göstermektedir." ${ }^{51}$ |lgaroğlu'na göre bedevîlikten hadarîliğe geçiş sürecinde karşılaştığı her zorluğu aşarak umrânın refahına doğru ilerleyen insan, hayatını biraz daha kolaylaştırmakta, bu durum ise mücadele edeceği zorlukları azaltacağından bedensel ve ahlakî bir gevşemeye sebep olmaktadır. ${ }^{52}$

Kılıç'ın tespitlerine göre ise "ibn Haldun, yabancılaşmayı, kişi iradesinin, mal ve servet karşısında yanlış tercihi olarak değerlendirirken, doyum bilmeyen arzuların peşinde yıpratıcı bir alana doğru kaydırıcı görür" ve İbn Haldun, "bolluk ve refahın, bozulma ve yabancılaşmaya sebep olduğunu sıkça belirtirken, üretim ve tüketimdeki hikmetin gözetilmediği, manevi denetimden uzak bir toplum örgüsünü itibare almış olmadır" yorumunu yapar. ${ }^{53}$ Yapılan değerlendirmelerden de

48 Muhammed Âbid el-Câbirî, “Niçin İbn Haldun?", çev. Harun Yılmaz, Dîvân Illmî Araştırmalar, 21/2 (2006), 15.

49 Operasyonelleştirme: "kavramların gözlemlenebilir sosyal etkinlikler halinde ifade edilmesidir. İşlemselleştirme sayesinde gözlemlediğimiz durumları ifade eden kavramları, ölçebileceğimiz, kaydedebileceğimiz ve analiz edebileceğimiz değişkenlere dönüştürürüz." Geniş bilgi için bkz. Gönç Şavran, Sosyolojide Araştırma Yöntem ve Teknikleri, 132.

50 Bu konudaki değerlendirmeleri için bkz. Ahmet Arslan, ibn Haldun (Ankara, Vadi Yayınları, 1999).

51 Tekin, "'Din'dârâne Yabancılaşma", 56.

52 Muhammet Caner llgaroğlu, İbn Haldun Düşüncesinde Sosyo-Ekonomik Değişme ve Ahlak," Al-Farabi International Journal on Social Sciences, 3/1 (March 2019), 10.

53 Kılıç, Yabancılaşma, 34-42. 
anlaşılacağı üzere İbn Haldun'un yabancılaşmayı andıran tespitlerinin, sonrasındaki süreklilik ve değişim ekseninde insanı merkeze alan birçok çalışmada ortaya konan düşüncelere referans olabilecek bir yoğunluğa sahip olduğu görülmektedir.

\section{Yabancılaşma Üzerine Yapılan Değerlendirmelerin Benzer ve Farklı Yönleri}

İbn Haldun'un değerlendirmelerinde "fitrata yabancılaşma, bedeviyette daha az hadarîyette ise daha çoktur" şeklinde bir vurgu ön plana çıkar. Burada geçen bedeviyet ve hadarîyet kavramlarının İbn Haldun'daki sosyolojik karşılıkları da modern dönem sosyologlarının toplum sınıflandırmaları ${ }^{54}$ ile benzerlik göstermektedir. Zira bu durum sosyolojinin kurucu babalarından E. Durkheim'i de rahatsız eden bir tedirginliğe tekabül ediyor. O tedirginlik, toplumsal işbölümünü gerçekleştirmiş modern organik toplum yapısına sadır olacak olan "anomi" olgusudur. ${ }^{55}$ İbn Haldun için asabiyetin bozucu etkisi ahlaki çöküş olurken Durkheim için de toplumsal bütünleşmenin ve organik toplum yapısının bozucu etkisi anomi olmaktadır. Zaman zaman anomi ve yabancılaşma kavramları arasındaki benzerliklere dikkat çekilmekte veya aynı fenomenin farklı adlandırmaları olduğunu, yabancılaşmanın anominin görünümlerinden biri olduğunu söylenmektedir. ${ }^{56}$ İbn Haldun'un hadarîlerle ilgili şu değerlendirmelerinde bahsi geçen bu benzerlik daha net görülebilmektedir. "Hadarîler, çeşit çeşit zevklerle, refahın getirdiği âdetlerle (menfaatlerine) yönelmekle, dünyevî arzuları üzerinde ısrarla durmakla sık sık karşılaştıkları için, birçok kötü ve çirkin huy ile nefisleri kirlenmiştir. Söz konusu durum kendilerinde hâsıl olduğu nispette, hayır ve fazilet yol ve vasıtalarından uzaklaşmışlardır. Hatta hal ve hareketlerindeki sıkılganlık bile yok olup gitmiştir. Onun için bunlardan birçoğunun toplantılarında, büyüklerinin ve mahremlerinin aralarında sövdükleri ve pis küfürler savurdukları görülür. Saygı müeyyidesi onları bu tutumlarından vazgeçirmez." "O halde Durkheim'e göre yabancılaşma (toplumsal sapma ya da anomi) toplumda dayanışmanın ve ortak değerlere bağlıı̆̆ın zayıflığı, dolayısıyla da kuralsızlıkla doğrudan ilgilidir." ${ }^{28}$ "Bedensel gevşeklik, çevresel şartlara karşı insanın dayanma direncini kırarken; ahlakî gevşeklik; arzuların, hazların ve refâhın cazibesine karşı insanı biçare kılmakta ve ahlakî açmazların oluşmasına sebep olmaktadır." ${ }^{\prime 9}$

54 Bu toplum sınıflandırmalarına başka örnekler olarak H. Spencer'in Homojen ve Heterojen, F. Tönnies'in Gemeinschaft (cemaat) ve Gesellschaft (cemiyet) şeklindeki sınıflandırmaları verilebilir. İlgi sınıflandırma ve yorumlar için bkz. Martin Slattery, Sosyolojide Temel Fikirler (Bursa: Sentez Yayınları, 2010); Abdurrahman Kurt, Din Sosyolojisi (Bursa: Sentez Yayınları, 2017).

55 Emile Durkheim, Intihar, çev. Özer Ozankaya (İstanbul: Cem Yayınevi, 2002), 275-295.

56 Muhammet Ertoy, Yabancılaşma Kader mi, Tercih mi? (Ankara: Lotus Yayınevi, 2007), 80.

57 İbn Haldun, Mukaddime, 1/327.

58 Ferhat Tekin, "Peter L. Berger'in Yabancılaşma Anlayışı: Diyalektik Bilincin Kaybı”, Beytulhikme An International Journal of Philosophy, 4/2 (December 2014), 33.

59 Muhammet Caner Ilgaroğlu, "ibn Haldun Düşüncesinde Sosyo-Ekonomik Değişme ve Ahlak", Al-Farabi International Journal on Social Sciences, 3/1 (March 2019). 
Slattery'nin sosyolojide temel fikirleri ele aldığı ilgili çalışmasında, Marx'ın yabancılaşma ve komünizm bağlantılı görüşlerini ${ }^{60}$ açımlamak üzere vurguladığı "üretim araçlarının herkesin ortak malı olduğu sınıfsız bir toplumda yabancılaşmanın tamamen ortadan kalkacağı"61 şeklindeki tespitleri, İbn Haldun'un fıtrat eksenli olarak betimlemeye çalıştığı yabancılaşma tespitlerinden farklılaşmaktadır. Her ne kadar Slattery, Marx ve yabancılaşma kavramı ile ilgili anlatısının sonunda kavramın sahip olduğu farklı anlam içerimlerine değinse de Marx'ın -“bir iş/çalışma analizi, insan doğası analizi ve sınıfsal sömürünün öznel etkisinin analizi"- şeklinde vurguladığı kullanımlarının "sosyolojik olmasa bile hatırı sayılır ahlakî bir güce sahip"62 olduğunu da eklemiştir. Buradan hareketle şu sorular eşliğinde bir tartışma da yapılabilir: İbn Haldun'un betimlediği yabancılaşma kavramının Marx'ın betimlediği yabancılaşmadan farkı ve benzerlikleri nelerdir? Ya da İbn Haldun'un toplumların temel karakteristiklerini ekonomik (geçim yollarının farklıııkları) ${ }^{63}$ göstergelerden okuması ile Marx'ın insanlık tarihini, çatışma kuramı üzerinden açıkladığı materyalist ekonomi okuması ile kastedilen şey aynı mıdır?64 Karl Marx, ekonomi göstergesini güç ve egemenliğin temel belirleyicisi bağlamında bir okumaya tabi tutarken İbn Haldun, ekonomiyi toplumların bedeviyetten hadarîyete geçişteki ahval ve şartlarının ayırt edici bir unsuru olarak ele alır. Yapılan karşılaştırmanın daha anlaşılır olması için biraz daha açımlanacak olursa; Marx'ın Yabancılaşma dediği durumların, özel mülkiyetle birlikte üretim araçlarına sahip olan (burjuvazi) ideolojinin ortaya çıkardığı, uygulamadan kaynaklı (çünkü bu uygulamanın olmadığı sosyalist bir toplum ideal ve beklentisi de mevcut) ${ }^{65}$ arızi bir durum söz konusu olurken; İbn Haldun'un yabancılaşmayı andıran tespitlerindeki ekonomi kurgusu, belli bir dönem ve ideoloji şartlarına bağlı kalmaksızın, bütün bireyleri içine alan bir muhataplığa ve geçişkenliğe sahip gibi görünmektedir. Yani her bir insan teki, ister feodal bir düzende, isterse de kapitalist ya da sosyalist bir sistemde olsun ekonomik anlamda "eşya" ile olan ilişkisinde fitrattan uzaklaşma, ahlaki bozulma ve çözülme potansiyeline sahip olabilmektedir. Marx'ın önceliği insanların eşya ile olan irtibatlarının, onlarda ortaya çıkaracağı muhtemel etki ve sonuçlarından ziyade, özgürlük bağlamında

60 Karl Marx, 1844 El Yazmaları, çev. Murat Belge (Istanbul: Birikim Kitapları, 2017), 110-113.

61 Slattery, Sosyolojide Temel Fikirler, 127.

62 Slattery, Sosyolojide Temel Fikirler, 132.

63 İbn Haldun, Mukaddime, 1/323.

64 Bu ve benzeri soruların akıllara gelmesiyle ilgili olarak, Süleyman Uludağ'ın hazırlamış olduğu Mukaddime baskısında "bedevî ve hadarî kavimlerin var olmaları tabiidir" başlığı altında, toplumların geçim yollarının farklı olması ile ilgili dipnot açıklamasında, bedevilikten hadarîliğe geçişi sağlayan yani medenîleşmeyi temin eden sebeplerin ekonomik olduğuna vurgu yapılıyor. Üretim ve tüketimin cemiyetlerin bünyeleri, yapı biçimleri ve içinden geçtikleri değişim süreci üzerinde tesiri olduğunun kısa ama özlü bir biçimde İbn Haldun tarafından gösterildiği ve bu açıdan da bu bölüme Sosyalistler ve Marksistlerin büyük bir ehemmiyet verdikleri de belirtilmiş. İlgili dipnot için bkz. İbn Haldun, Mukaddime, 323. Ayrıca Abdurrahman Kurt, Din Sosyolojisi kitabındaki İbn Haldun'la ilgili kısımda yapılan benzer yorumlara dikkat çekerek, Marksist çizgide yayın yapan bilim ve Ütopya dergisinin de "İslam'ın Marks'ı İbn Haldun" şeklindeki manşetine gönderme yapmıştır. bkz. Abdurrahman Kurt, Din Sosyolojisi (Bursa: Sentez Yayıncılık, 2018), 96.

65 Marx, 1844 El Yazmaları, 107-123. 
kendi özünü gerçekleştiremeyecek olan insanın çalışma şartlarının ortaya çıkardığı durumlarla ilgilidir. Farklı olarak, Marx'ın kapitalistlerin de yabancılaştığı yönündeki eleştirilerinde öne çıkan betimlemelerinin, İbn Haldun'un tespitleriyle daha çok benzeştiği söylenebilir. Çünkü Ollman'a göre “Marx'ın kapitalistlerde gözlemlediği başlıca özellikler açgözlülük, zalimlik ve ikiyüzlülüktür." ${ }^{\prime 6}$

Modernizmin ortaya çıkardığı durumlarla ilgili olarak ortaya atılan eleştiri ve tartışmalarda da yabancılaşma, anomi ve küreselleşme konuları ağırlıklı bir yer tutar. Eleştirel bir tutumla konuya yaklaşanların görüşlerindeki özellikle yabancılaşma vurgusu olan ya da yabancılaşmayı andıran çeşitli görüş ve değerlendirmelerden bazılarına bakıldığında; yukarıda bahsedilen yabancılaşma tezahürlerine dair birçok örnek tespit bulunabilir. Frankfurt Okulu başta olmak üzere modernizmin insan merkezli olarak ortaya çıkardığı hoşnutsuzluklar birçok düşünür ve sosyolog tarafından dile getirilmiştir. Hatta denilebilir ki Frankfurt Okulu, Marx'ın sosyolojik düzlemde bıraktığı yabancılaşma kadrajını daha da genişleterek felsefi, metafizik ve ahlaki alanlara doğru kaydırmıştır. Kültür endüstrisi bağlamında insanın özgürleşimi ve kültürün metalaşması ve tüketim nesnesine dönüşmesi gibi hususlarda ciddi eleştiriler getirmişlerdir. ${ }^{67}$ "Tüketim, postmodern insanın biyo-psişik yaşamını devam ettirme yolunda bir amaç haline dönüşmüştür." ${ }^{68}$ Kurt'un modernlik eleştirileri bağlamında vurguladığı şekliyle ifade edilecek olursa; "bir ideoloji haline getirilen modernlik projesinin beraberinde getirdiği materyalizm ve tüketim çılgınlığı, geleneksel toplumların kültürel kodlarını zayıflatarak toplumun çözülmesine köksüzlüğe ve yabancılaşmaya yol açtı. ${ }^{169}$ Aynı şekilde Zygmunt Bauman ${ }^{70}$ ve Jean Baudrillard, ${ }^{71}$ gibi düşünürlerin de modernlik sonrası yaşanan değişim süreçleri ile ilgili eleştiri ve değerlendirmeleri mevcuttur. Bu eleştirilerinin merkezinde insanın var olan özüne/doğasına yönelik bir beklenti çıtasının varlığından bahsedilebilir ki ancak bu şekilde yapılan eleştiri ve yoklamaların tekabül ettiği ve göndermede bulunduğu bir karşılık bulunsun. Yani bu düşünürlerin, kendi dünya görüşleri çerçevesinde insana dair yaşanan savrulmaların karşılaştırma ve analizini yapabilecekleri bir "insani varoluş zemininin" var olduğunu söylemeye çalışıyoruz. Bazı modernizm ve postmodernizm eleştirileri, bu insani varoluş zemini üzerinden yapıldığı için bir asıldan, öz benlikten uzaklaşma ve yabancılaşma şeklinde değerlendirebilecek hususiyetlerin de bu eleştirilerin içinde mündemiç olduğu söylenebilir. Asırlar

66 Ollman, Yabancılaşma, 248.

67 Bilal Bekalp,"Frankfurt Okulu'nun Temel Eleştiri ve Amaçları", Sosyal Bilimler Metinleri 2019 / 1 (Mayıs 2019), 21-23.

68 Nejdet Durak - Muhammet İrğat, “Değersizleşme ve Yabancılaşma Bağlamında Tüketim Ahlâkı ve İnsan”, Ilahiyat Akademi, 3 (Eylül 2016), 83.

69 Kurt, Din Sosyolojisi, 241-242. Ayrıca bz. Gülüşan Göcen, “ibn Haldun'un Toplum ve İnsan Yaklaşımının Günümüze Düşen İzdüşümleri: Tüketim Toplumu ve Narsist İnsan" Toplum Bilimleri Dergisi, $7 / 14$ (Temmuz 2013), 175-198.

70 Zygmunt Bauman, Postmodernizm ve Hoşnutsuzlukları, çev. İsmail Türkmen (İstanbul: Ayrıntı Yayınları, 2007); Zygmunt Bauman, Modernite, Kapitalizm, Sosyalizm, çev. F. Doruk Ergun (İstanbul: Say Yayınları, 2013), 95-107.

71 Jean Baudrillard, Tüketim Toplumu, çev. Hazal Deliceçaylı ve Ferda Keskin, (İstanbul: Ayrıntı Yayınları, 2004), 225253; Jean Baudrillard, Simülakrlar ve Simülasyon, çev. Oğuz Adanır (Ankara: Doğu-Batı Yayınları, 2003). 
öncesinde İbn Haldun'un insanın eşya ile olan münasebetindeki dengesizlik ve israfın, fıtrattan uzaklaşmaya, çözülmeye -ve dahi yabancılaşmaya- sebep olabileceği tespitleriyle modernlik sonrası insanın yaşadığı sorun ve krizler konusunda yapılan tespit ve yorumlar benzerlik göstermektedirler. Kendisinden uzaklaşılan şeyin isimlendirilmesi hususunda farklı (dini, felsefi, ahlaki) terminolojiler (fıtrat, öz, bilinç, benlik, öz bilinç, öz benlik vb.) kullanılsa da uzaklaştıran, bozan, ifsat eden, değiştiren ve dönüştüren sebep ve süreçler hususunda bir benzerlik ve fikir birliği olduğu görülmektedir.

\section{Sonuç}

Yabancılaşma kavramı, merkezinde insan ve toplum olan her bir araştırmacının yaşanan değişim süreçlerini kendisiyle anlamlandırıp açıklamaya çalıştığı bir kavram olarak karşımıza çıkmaktadır. Felsefî, teolojik, ahlaki, edebi ve daha birçok açıdan insanın yaşamış olduğu yabancılaşmaya yönelik değişik hususlar yinelenerek gündeme gelmeye devam etmektedir. İnsan ve topluma dair gerçekçi çözümlemeler yapabilmek için bu türden yapılan her bir çalışmaya, daha yakından ve derinlikli olarak bakabilmek ve yorumlayabilmek gerekir. Günümüz araştırmacıları olarak kadim geleneğimizden gelen bilgi mirasını, güncel olanla buluşturarak yeni bakış açıları elde etmeye çalışmak en önemli önceliklerimiz arasında yer almaktadır. Üzerinde durmaya ve yorumlamaya değer bulduğumuz, sosyal bilimler açısından kendisiyle ilgili her türden çalışmayı hak eden isimlerden biri olarak İbn Haldun, yukarıda bahsi geçtiği şekliyle insanı ve toplumu anlama yolunda orijinal tespit ve değerlendirmeleri ile önemli katkılar sunmuştur. Hadari toplum yapıları ile ilgi çözümlemelerinde her insanın muhtemel olarak yaşayabileceği (israf, haddi aşma, lüks, konfor, fantezi, aşırı üretim ve tüketim vb.) ${ }^{72}$ durumları tespit ederek evrensel bir yabancılaşma tanım ve çerçevesi ortaya çıkarmıştır. Bu evrensellik kıstasını, modern dönem ve sonrasında insana dair yapılan çözümlemelerde de görmek mümkün olduğu için vurgulandığı belirtilmelidir.

Yabancılaşma kavramı, "geleneksel dönem" ve "modern dönem ve sonrası" olmak üzere iki hat üzerinden anlatılmaya çalışılsa, İbn Haldun'a ait çözümlemelerin, geleneksel döneme ait olan kısmı rahatlıkla anlatabilecek bir potansiyele sahip olduğu söylenebilir. Hakeza modern dönem ve sonrası için de İbn Haldun'un tespitlerinin teşmil edilebileceği alanların var olduğuna işaret edilmişti. Hattın ikinci kısmı olan modern dönem ve sonrasını ise daha çok Karl Marx ve takipçileri ile bazı eleştirel kuramcıların temellendirdiği yabancılaşma teorileri örnek olarak verilebilir. Geleneksel dönemi temsil eden yabancılaşmada hayatın akışkanlığı içinde, kendiliğinden oluşan yabancılaşma süreçlerinden bahsedilirken; modern dönem ve sonrasındaki yabancılaşmada sunî, müdahale edilebilir, ideolojik, manipülatif olan bağlamlara yapılan çeşitli göndermelerle sınırlandırılmış/tahsisli yabancılaşma süreçlerinden bahsedilebilir. Bu ikinci hattaki

72 İbn Haldun, Mukaddime, 1/106. 
yabancılaşma türünde kontrol edilebilir ve müdahale edilebilir sebep ve süreçler daha fazla yer alırken; birinci hatta yer alan yabancılaşma anlatımında toplumun (hadari umranın) kendi iç şartları içinde oluşmuş bir devingenlikten ve müdahalesizlikten bahsedilebilir. Hadarî toplum yapısında insanları hile ve aldatmaya sevk eden şey, daha çoğuna ve daha konforlusuna sahip olma hırs ve açgözlülüğü olmaktadır. Bu durum ise fıtratlarından uzaklaşan insanlara dinlerini, maneviyatlarını ve değerlerini de unuttukları bir yabancılaşmayı ve anomiyi yaşatmaktadır. Bu tespitlerin benzer şekilde modern toplum ve sonrasında da devam eden bir sürekliliğinin olduğu "tüketim toplumu" kavramsallaştırması içinde anlatılmaya çalışıldı. İkinci hat kategorisinde yer alan kuramcılardan bazıları, daha çok felsefi argümanlarla destekledikleri iddialarını (bireyin özgürlüğü ve özbenlik yitimi vb.) yer yer Hegel ve öncesindeki filozoflara atıfta bulunarak temellendirmeye çalışmışlardır. Illahiyat disiplini içerisinden yabancılaşmayı açıklamaya çalışan araştırmacıların ise konuyu, daha çok İbn Haldun'un fıtrat eksenli yabancılaşma tespitlerine benzer şekilde anlamaya ve açıklamaya çalıştıkları görülmüştür. Yabancılaşma, insan ve toplum üzerine derinlikli araştırma yapan herkesin bir şekilde buluşabileceği ortak bir payda olarak görünmektedir. Söz konusu insan olunca, elbette ona dair yapılacak olan açıklamaların ortak paydasının geniş olması da normal karşılanmalıdır. 


\section{Kaynakça}

Aron, Raymond. Sosyolojik Düşüncenin Evreleri. çev. Korkmaz Alemdar. 8. Baskı, İstanbul: Kırmızı Yayınları, 2010.

Arslan, Ahmet. Ibn Haldun. Ankara: Vadi Yayınları, 1999.

Arslantürk, Zeki. Sosyal Bilimciler lçin Araştırma Metod ve Teknikleri. İstanbul: Çamlıca Yayınları, 2008.

Baş, Selma. Türk Hikâyeciliğinde Yabancılaşma (1950-1980). Van: Yüzüncü Yıl Üniversitesi, Sosyal Bilimler Enstitüsü, Doktora Tezi, 2003.

Baudrillard, Jean. Simülakrlarve Simülasyon. çev. Oğuz Adanır. Ankara: Doğu-Batı Yayınları, 2003.

Baudrillard, Jean. Tüketim Toplumu. çev. Hazal Deliceçaylı - Ferda Keskin. İstanbul: Ayrıntı Yayınları, 2004.

Bauman, Zygmunt. Postmodernizm ve Hoşnutsuzlukları. çev. İsmail Türkmen. İstanbul: Ayrıntı Yayınları, 2007.

Bauman, Zygmunt. Modernite, Kapitalizm, Sosyalizm. çev. F. Doruk Ergun. İstanbul: Say Yayınları, 2013.

Bekalp, Bilal. "Frankfurt Okulu'nun Temel Eleştiri Ve Amaçları". Sosyal Bilimler Metinleri, 1 (Mayıs 2019), 15-24.

Çağıl, Orhan Münir. "Metafizik Zaviyeden Yabancılaşma Problemi ve Hegel'in Panlojist "Intikal Ve Telif (Terkip)" Felsefesi". İstanbul Üniversitesi Hukuk Fakültesi Mecmuası. XLIV/1-4 (1980), 137-223.

Dalkılıç, Bayram - Akyüz, Yakup. “Platon'un Felsefesinde Yabancı/laş/tır/ıl/ma Sorununa Giriş Denemesi". Hikmet Yurdu 11/21 (Haziran, 2018), 9 - 27.

Doğan, D. Mehmet. Büyük Türkçe Sözlük. İstanbul, İz Yayıncılık: 1996.

Durak, Nejdet - İrğat, Muhammet. "Değersizleşme ve Yabancılaşma Bağlamında Tüketim Ahlâkı ve İnsan". Illahiyat Akademi 3 (Eylül 2016), 75-88.

Durkheim, Emile. Intihar. çev. Özer Ozankaya. İstanbul: Cem Yayınevi, 2002.

El-Câbirî, Muhammed Âbid. "Niçin İbn Haldun?". çev. Harun Yılmaz. Dîvân Ilmî Araştırmalar, 21/2 (2006), 9-16.

Erdiç, Şaban. "İslam Düşüncesinde Yargı ve Siyaset Illişkisi: Ebû Hanîfe Üzerine Sosyolojik Bir Değerlendirme". Cumhuriyet Illahiyat Dergisi 25 / 1 (Haziran 2021), 293-310.

Ergil, Doğu. "Yabancılaşma Kuramına Illk Katkılar". Ankara Üniversitesi SBF Dergisi 33 / 03 (Mart 1978), 93-108. https://doi.org/10.1501/SBFder_0000001363

Ertoy, Muhammet. Yabancılaşma Kader mi, Tercih mi? Ankara: Lotus Yayınevi, 2007.

Göcen, Gülüşan. “ibn Haldun'un Toplum ve İnsan Yaklaşımının Günümüze Düşen İzdüşümleri:Tüketim Toplumu ve Narsist Insan" Toplum Bilimleri Dergisi $7 / 14$ (Temmuz 2013), 175-198.

Görgün, Tahsin. "Ibn Haldun, Görüşleri”. Türkiye Diyanet Vakfı İlâm Ansiklopedisi. 19/543555. Ankara: TDV Yayınları, 1999. 
Gürses, İbrahim. "Jung'cu Arketip Teorisi Bağlamında Tasavvufî Öykülerin Değerlendirilmesi: Sîmurg Örneği" T.C. Uludağ Üniversitesi Ilâhiyat Fakültesi Dergisi 16/1, (2007), 77-96.

Hasanov, Bahram. "ibn Haldun'da Asabiyet Kavramı - Maurıce Halbwachs'ın "Kolektif Hafıza" Kavramı İle Bir Karşılaştırma". Elektronik Sosyal Bilimler Dergisi, 15/59, (2016), 1437-1446. DOI: 10.17755/esosder.263245

Ilgaroğlu, Muhammet Caner. "İbn Haldun Düşüncesinde Sosyo-Ekonomik Değişme ve Ahlak". Al-Farabi International Journal on Social Sciences 3/1 (March 2019), 10-16.

İbn Haldun, Mukaddime. haz. Süleyman Uludağ. 1. Cilt, İstanbul: Dergâh Yayınları, 2009.

Kafka, Franz. Dönüşüm. çev. Nafer Ermiş. Ankara: İmge Kitabevi, 2008.

Karaca, Faruk. "Din ve Yabancılaşma: İmkânlar, Fırsatlar ve Tehlikeler". Ilahiyat Akademi 3 (Eylül 2016), 45-54.

Kayapınar, Akif. "ibn Haldun'un Asabiyet Kavramı: Siyaset Teorisinde Yeni Bir Açılım”. İslâm Araştırmaları Dergisi 15 (2006). [ibn Haldun Özel Sayısı-I], 83-114.

Kiraz, Sibel. "Yabancılaşmanın Kökeni Üstüne". FLSF (Felsefe ve Sosyal Bilimler Dergisi) 12 (Güz 2011), 147-169.

Koç, Bekir. "Yabancılaşma ve Modern Tüketim Mabetleri Üzerine Bir Çözümleme”. Bingöl Üniversitesi Ilahiyat Fakültesi Dergisi 1/2 (Ekim 2016), 205-225.

Közleme, Olgun. “ibn Haldun Düşüncesi'nde Geçim ve Zenginliğin Psiko-Sosyal Boyutları”. Toplumbilimleri Dergisi. 7/13 (2013), 363-376.

Kurt, Abdurrahman. Din Sosyolojisi. Bursa: Sentez Yayıncılık, 17. Baskı, 2018.

Marx, Karl. 1844 El Yazmaları. çev. Murat Belge. İstanbul: Birikim Kitapları, 11. Baskı, 2017.

Mevlana Celaleddin Rumi. Mesnevi. çev. Veled İzudak. 1. Cilt. İstanbul: Milli Eğitim Bakanlığı Yayınları, 1990.

Okumuş, Mesut - Dinç, Ömer(ed.). Uluslararası İbn Haldûn Sempozyumu. Ankara: Çorum Belediyesi Kültür Yayınları, 2015.

Ollman, Bertell. Yabancılaşma, Marx'ın Kapitalist Toplumdaki Insan Anlayışı. çev. Ayşegül Kars. İstanbul: Yordam Kitap, 2012.

Özden, H. Ömer. "Bir Ahlâk Problemi Olarak Yabancılaşma ve Yahya Kemal". Ilahiyat Akademi / 3 (Eylül 2016), 101-112.

Özel, İsmet. Üç Mesele-Teknik-Medeniyet-Yabancılaşma. İstanbul: Çıdam Yayınları, 1992.

Özel, İsmet. ÜçZZor Mesele- Teknik, Medeniyet-Yabancılaşma. İstanbul: TiYO Yayıncılık, 2016.

Polat, Serkan - Polat, Semra Aktaş. "Bedevi Ümrandan Hazeri Ümrana Geçiş: Boş Zaman Kültürüne Bir Bakış". Kastamonu Üniversitesi Iktisadi ve Idari Bilimler Fakültesi Dergisi 12 (Nisan 2016), 572-583.

Sambur, Bilal. “Din, Ülfet ve Yabancılaşma”. Illahiyat Akademi 3 (Eylül 2016): 67-74.

Skirbekk, Gunnar- Gilje, Nils. Antik Yunan'dan Modern Döneme Felsefe Tarihi. çev. Emrah Akbaş - Şule Mutlu. Ankara: Kesit Yayınları, 4. Baskı, 2011.

Slattery, Martin. Sosyolojide Temel Fikirler. İstanbul: Sentez Yayınları, 4. Baskı, 2011. 
Şavran, Gönç, Temmuz. "Nicel ve Nitel Araştırmalarda Kullanılan Araştırma Teknikleri". Sosyolojide Araştırma Yöntem ve Teknikleri. ed. Temmuz Gönç Şavran. 64-104. Eskişehir: Anadolu Üniversitesi Yayınları, 2012.

Şavran, Gönç, Temmuz. "Araştırma Probleminin Oluşturulması ve Uygun Yöntem ve Tekniklerin Seçilmesi". Sosyolojide Araştırma Yöntem ve Teknikleri. ed. Temmuz Gönç Şavran. 106-143. Eskişehir: Anadolu Üniversitesi Yayınları, 2012.

Tekin, Ferhat. "Peter L. Berger'in Yabancılaşma Anlayışı: Diyalektik Bilincin Kaybı". Beytulhikme An International Journal of Philosophy 4/2 (December 2014), 29-48.

Tekin, Mustafa. "Mevlâna Celâleddin Rûmi'de Din ve Yabancılaşma". İnönü Üniversitesi İlahiyat Fakültesi Dergisi 1/1 (Haziran 2010): 101-118.

Tekin, Mustafa. "'Din'dârâne Yabancılaşma". Illahiyat Akademi 3 (Eylül 2016): 55-66.

Tezcan, Mahmut. "Gençlik ve Yabancılaşma". Ankara University Journal of Faculty of Educational Sciences (JFES) 18/1 (Eylül 2019):121-127. https://doi.org/10.1501/ Egifak_0000001088

Türk Dil Kurumu. Türkçe Sözlük. Ankara: Türk Dil Kurumu Yayınları: 2005.

Uludağ, Süleyman. İbn Haldun. Ankara: Türkiye Diyanet Vakfı Yayınları: 1993.

Uludağ, Süleyman. "ibn Haldun". Türkiye Diyanet Vakfı İslâm Ansiklopedisi. 19/538-543. Ankara: TDV Yayınları, 1999.

Uzunkaya, Ferhat. 1980 Sonrası Türk Romanında Yabancılaşma. Ardahan: Ardahan Üniversitesi, Sosyal Bilimler Enstitüsü, Doktora Tezi, 2020.

Zencirkıran, Memet. Sosyoloji. Bursa: Dora Yayıncılık. 8. Baskı, 2019. 